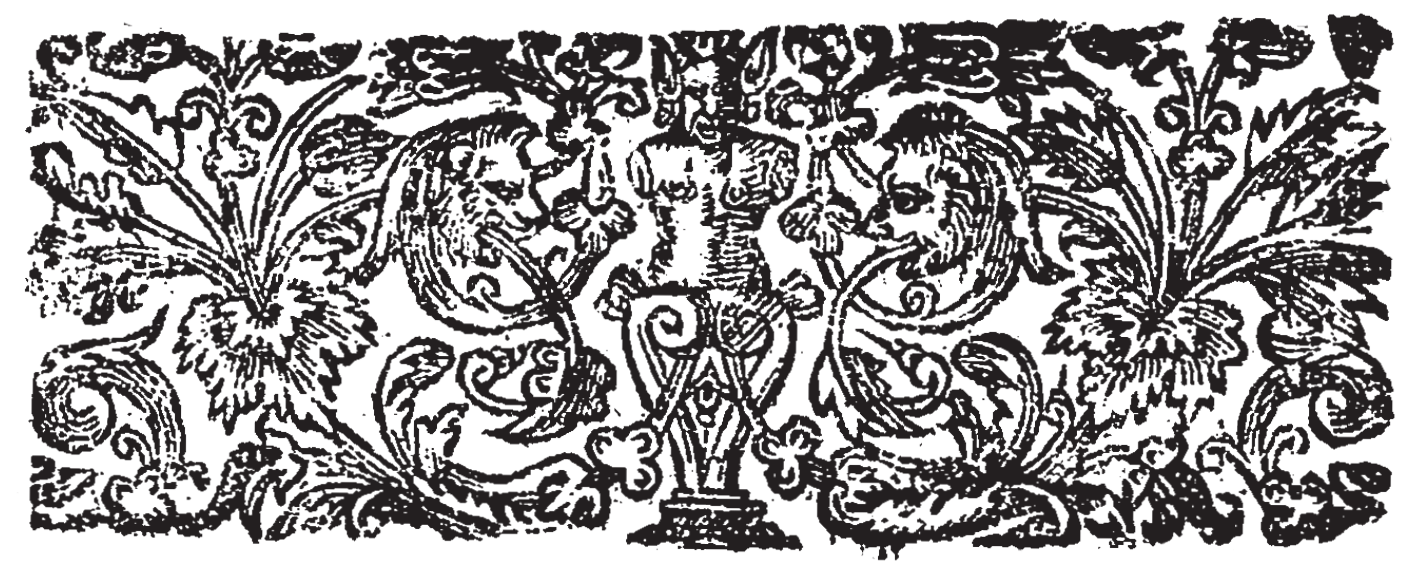

Restoration Volume 41.2

\title{
The Role of Manuscript Newsletters in Charles II's Performance of Power ${ }^{1}$
}

\author{
Erin M. Keating \\ University of Manitoba
}

Addressing Sir Richard Newdigate on November 29, 1677, a newsletter dispatched from Whitehall imparts the following piece of gossip: "Capt Lloyd advises me that $\mathrm{Mr}$ Palmer is dash't out of ye Rolle of Justices by ye Kings Imediate hand. ye reason I presume I need not tell your Worp." ${ }^{2}$ A reader familiar with Charles II's court would have known the reason to which the newsletter writer, likely Henry Muddiman, alludes-Mr. Palmer being the recalcitrant husband of the king's former mistress, Barbara Palmer, Duchess of Cleveland and, thus, not an individual in line in any way for the king's favor. ${ }^{3}$ What is interesting about this piece of gossip is the way that it reveals the greater privilege allowed to the manuscript newsletters to convey private information (in comparison to the printed gazettes), yet simultaneously demonstrates the writer's need to resort to innuendo and implication when touching on sensitive matters, such as evidence of a king's petty jealousy and insinuations of a mistress's influence in political appointments. ${ }^{4}$ Like scandalous rumors whispered between friends, Muddiman's rhetorical subterfuge serves to affectively shape a privileged community of readers imaginatively linked to the king and his inner circle of friends and advisors.

Muddiman's evocation of "ye Kings Imediate hand" — an image of a swift, decisive response but also of immediacy and closeness to the person of the king-complements the gossipy tone of the item, bringing the reader into a shared sense of 'true' understanding of the intimate motives of the king while grounding that intimacy in the king's physical body, the hand that held the quill that "dash'd" out Mr. Palmer's name. The twin elements of seeming proximity to the king's thoughts, motives, and feelings, and an awareness of his physical presence are activated in the brief moments in which the newsletters take the monarch as their subject. This affective intimacy is enabled by the unique cultural space 
occupied by the manuscript newsletters during the 1670s-acting as a literal supplement to the printed news offered in the official paper, The London Gazette, and, through this supplementarity, imaginatively shaping an elite readership and figuratively connecting that readership to the person of the king by tracing his movements between London and the many places (Newmarket, Woolwich, Windsor, Portsmouth) where he travelled in his active pursuit of pleasure. ${ }^{5}$

As we shall see, Charles's cultivation of the "Merry Monarch" persona-pleasure seeking, easy-going, accessible-reinforced the illusion of his availability suggested by these newsletters written during the 1670s. Historian Brian Weiser, by contrast, has documented the king's increasing withdrawal from the public and increasingly secretive behavior towards his inner circle of advisors during these years. ${ }^{6}$ In the pages that follow, I will demonstrate how these manuscript newsletters contributed to Charles's paradoxical performance of elusiveness/availability through their supplementarity, the dual nature of which, as Jacques Derrida reminds us, is to act both as "surplus" and as something which "adds only to replace ... interven[ing] or insinuate[ing] itself in-the-place-of." Both the medium and the content of these letters combined to contribute to a new form of political representation underwritten by the monarch's physicality — both the sexuality that Kevin Sharpe describes as integral to Charles's representations of power and the vigor demonstrated through his love of physical pastimes - and his performance of the contradictory qualities of strength/vulnerability, sanctity/profanity, and singularity/typicality that enable public intimacy. ${ }^{8}$

That manuscript newsletters which circulated throughout Europe played an important role in the spread of information during the seventeenth century and to the rise of the printed newspaper is a critical commonplace; they also continue to be an important source of historical data for modern historians. However, what has not been explored is the role that the manuscript newsletters written from Whitehall played in the creation and perpetuation of an image of Charles II as a monarch available to his common subjects, an availability that carried both positive and negative connotations. Along with a number of other artistic media during the 1670s and early 1680s that worked to create an affective bond between Charles and his subjects, these newsletters built upon the king's apparent accessibility to allow their readers to further imagine him as one of the people. According to Lorenzo Magalotti's Relazione d'Inghilterra, written while he was travelling through Europe in the service of the Grand Prince Cosimo, this image of Charles as a mere man was reinforced by the king's own "affability," a quality that Magalotti ascribed to "the habit formed in [Charles's] youth of adopting the humble manners of a poor and private nobleman" while in exile on the continent. ${ }^{9}$ The king reinforced this relationship between his personality and his humbling war experience by frequently recounting the story of his escape from the battle of Worchester, which required him to don the clothing of a commoner and, at times, masquerade as a servant. ${ }^{10}$ While the reality of access to the king declined fairly quickly after the early years of his reign and fluctuated with the political upheavals at court, the illusion that Charles created of his own openness and affability remained an important part of his public persona throughout his time on the throne. ${ }^{11}$ 
The ambiguity of perception inherent in the merry monarch persona placed the burden of interpretation on those surrounding the king and was embraced by propagandists on all sides of the political spectrum as avenues for panegyric and for criticism; it was also essential to creating Charles's representations of power and his celebrity. ${ }^{12}$ In his comprehensive study of the representational strategies of the late Stuart monarchs, Sharpe argues that the contradictions and ambiguities that have made it so difficult for historians to create consistent and definitive descriptions of Charles II and his reign are, in fact, part of the strength of that reign. Writing about the different genres used to reconstitute monarchy after the Restoration, Sharpe argues that the "very ambiguity" of written representations "saved and sustained Charles's kingship ... for a nation that could not in 1660 fully accept the realities of division, demystification and political conflict, the mix of older vocabularies and tropes with new languages helped to reconstitute the polity."13 Thus, before we can fully understand the role of the manuscript newsletters in contributing to the creation of an affective bond between Charles and his subjects based upon this public image of the king, we need to look briefly at the ways that Charles's frequent eschewing of the sacred elements of kingship contributed to this ambiguous trope of elusiveness/availability and the ways that this was taken up by artists and writers supporting this public representation of their king.

Much has been said about the many criticisms of Charles II's pursuit of pleasure, to which he was so dedicated that Tim Harris remarks, "whoring ... seemed to be one of the few things [Charles] was good at." ${ }^{14}$ While Restoration writers often singled out the king's moral laxity as a topic for satire and criticism, he was also censured for his profligate spending, his apparent laziness, and his tendency to break his word. As many of his contemporaries complained, Charles's openness and good nature were bound up with his pursuit of pleasure and often served only to lessen his own work and trouble - the king "was not stirring nor ambitious, but easy, loved pleasures, and seemed chiefly to desire quiet." ${ }^{15}$ As Pepys puts it in his diary, "it is not in [the king's] nature to gainsay anything that relates to his pleasures." ${ }^{16}$ Those who had frequent dealings with Charles quickly learned that his word and support were not things upon which they could depend: "He had a softness of temper, that charmed all who came near him, till they found how little they could depend on good looks, kind words, and fair promises, in which he was liberal to excess, because he intended nothing by them but to get rid of importunity." ${ }^{17}$ Seen through these lenses, Charles's good nature was easily reinterpreted as lazy and self-serving.

Recent reassessments of Charles's self-representation, however, have questioned the assumption that these aspects of his persona undermined his authority or effectiveness. Sharpe has persuasively argued that the king self-consciously positioned himself as a lover to the nation in opposition to the image of the father-king represented by his forbears, spinning sexual desire and potency into a form of political power. ${ }^{18}$ Harris notes the ambiguity of satires written by the court circle, claiming that the poetry of John Wilmot, Earl of Rochester related to the king's sexual profligacy might be as celebratory as it is critical. ${ }^{19}$ Early secret histories about Charles, like Sébastien Brémond's Hattigé, ou Les Amours de Roy de Tamaran (1676), also display an interpretive ambiguity regarding the king's sexual nature; while Charles is represented as weakened by his affection for the Duchess of 
Cleveland (Hattigé in the text), he ends the story as a triumphant comic hero, in possession of a new mistress, whom he has secured through a partner swap. ${ }^{20}$ All of these cases reveal the essential ambiguity of Charles as royal lover.

The many shifts in Pepys's attitude toward the "commonness" of his monarch further highlight the fluidity of reception that an emphasis on Charles's physical nature could be met with. From his often-quoted remark "that a King and all that belong to him are but just as others are," inspired by one of the king's dogs dirtying the boat during the Charles's entry into England, to his observation, upon spending more time working in the company of the Duke of York and the king, that "the more a man considers and observes them, the less he finds of difference between them and other men," it is clear that Pepys often struggles to reconcile his image of how a monarch should be with the man standing in front of him. ${ }^{21}$ This discomfort with the physical nature of the king is most apparent in Pepys's complaints in the diary that Charles lowered himself through his many affairs, a behavior "which is very mean methinks in a prince." ${ }^{22}$ Even so, Pepys often aligned himself with the desires of his monarch, fantasizing about those mistresses, particularly the Duchess of Cleveland. Pepys owned a portrait of the Duchess, an image that Rachel Weil reminds us "created a bond between Charles and his subjects as desirers of the same woman." ${ }^{23}$ Pepys took this even further, mimicking the king's highly visible liaisons with actresses like Mary "Moll” Davis and Nell Gwyn in his own dalliances with Elizabeth Knepp, thus "imaginatively stand[ing] in for the king" in his sexual pursuits. ${ }^{24}$

The polyvalence inherent in the king's persona would have been even stronger for the majority of his citizens, who, unlike Pepys, had little interaction with the king beyond the occasional public glimpses and the written and oral representations of their monarch that circulated from London out into the English countryside. This image was created by the many types of circulating print, manuscript, and oral material that seemingly provided people with access to the king and thus were a ripe source for the warring political factions at the time - the satires, political pamphlets, parallel plot dramas, secret histories, and the manuscript newsletters' reports that touched on the king's activities. ${ }^{25}$ This textual material was imaginatively layered upon Charles's actual visibility — whether in the playhouse, walking in the park, traveling about the countryside en route to one of his many palaces or pleasure spots, or touring the English shipyards and coastal fortifications. For them, the image of the people's king was a potent persona, the ambiguity of which left a great deal of interpretive power in the hands of Charles's subjects. The role of the individual in shaping and interpreting the persona of their monarch only added to its seeming solidity, the interpretive work creating a layer of belief uniting the many textual and visual impressions upon which the unified persona was based. Yet, as Roach reminds us, "just because such icons exist only in other people's imagination of them doesn't mean they're unreal." 26 The persona of Charles created by his circulation, both physically and symbolically, had material effects on his ability to perform power and on the afterlife of his reign.

Roach has argued for Charles II as one of the first modern celebrities, as a figure who "exud[ed] the most intense of the contradictory qualities that reliably excite the fascination of It: vulnerability in strength, profanity in sanctity, and intimacy in public." ${ }^{27}$ That final paradox, intimacy in public, is a quality shared by the medium of the manuscript 
newsletter itself, which carried with it the intimate associations of a familiar letter, whether it was framed as a direct address or organized by dated items as many of the letters were, despite the recipients' knowledge that his was merely one of many identical copies being sent out by the writer. Restoration readers' desire for the affective privacy conveyed through letters despite their publicity through entrepreneurial copying or print is evident in the rise of epistolary fiction "for the first time as a genre of real importance" during this period, as readers were drawn to the personal connection created by the genre in works such as Aphra Behn's first volume of Love-letters between a Nobleman and his Sister (1684) and Sir Roger L'Estrange's 1678 translation of Lettres Portugaises. ${ }^{28}$ This impression of intimacy was so valued that in 1696, Ichabod Dawks attempted to mimic this feeling in print, getting a special script font cut for his paper Dawks'News-Letter and beginning each issue with a "Sr." ${ }^{29} \mathrm{In}$ spite of the seeming novelty of this mode of printing the news, Dawks's paper was not a mere fad; it lasted twenty years until it finally ceased publication in $1716 .{ }^{30}$

Like Roach's images or icons, manuscript newsletters that detailed the activities of the king were able to create a "ghostly semblance" of the monarch through reports that gave access to the movements of the court, themselves taking the place of the body of the monarch, acting its as supplement. ${ }^{31}$ Through their reports about court favorites, they also provided seeming insight into the feelings and thoughts of the king, thus building an illusion of intimacy between that monarch and his subjects through the layers of information and, particularly, through the repeated insistence that their information was privileged and supplementary to public knowledge. Like gossip, this type of supplementarity is always both literal and symbolic; it "demands a process of relatedness among its participants; its Is inevitable turn into a we," a "we" that in this case yokes the newsletter recipients to their king and his court. ${ }^{32}$ To demonstrate how they enabled this affective community, it is now necessary to turn to the newsletters themselves.

The manuscript newsletters that were written from London during the years after the restoration of Charles II have been a rich source of historical data for scholars but have not traditionally been objects of study in themselves. ${ }^{33}$ Historians who do address the role of the newsletters in seventeenth-century Europe tend to see them as precursors to printed news gazettes. David Randall argues for "the newspaper's roots in the news letter," implying that the manuscript newsletters were of secondary importance to print in the late seventeenth century. ${ }^{34}$ Similarly, William Powell argues that newsletter writers such as John Pory "helped create an atmosphere that led to the establishment of the printed newspaper in England," while James Sutherland, in his study of Restoration newspapers, discusses newsletters almost solely as sources for the unofficial papers that sprang up after the lapse of the licensing act in $1679 . .^{35}$

More recent scholarship has challenged this teleological view of the relationship between manuscript and printed news. Heiko Droste claims that after the advent of printed newspapers, "the handwritten newspapers survived and actually flourished by adopting new functions" and, as Harold Love strongly argues in his study, Scribal Publication in Seventeenth-Century England, manuscript remained an important mode of publication right up to the end of the century, and well into the eighteenth century. ${ }^{36}$ 
Rachael Scarborough King sees print and manuscript news as "work[ing] in tandem" but, with the lack of editorial guidance in the newsletters, manuscript in particular "provided a venue to strengthen one's news judgment," an important skill during the Restoration. ${ }^{37}$ Far from being merely a way to convey information, the survival of manuscript newsletters after the advent of printed news indicates that they served different purposes despite their seeming similarity to print during the period under discussion. ${ }^{38}$

Falling under Love's category of "entrepreneurial publication," the manuscript newsletters continued to play an important role alongside the printed gazettes during the late seventeenth century, supplementing the public news with additional details and occasional comment on the information being conveyed. ${ }^{39}$ The writers often allude to the supplementary nature of their products, explicitly referencing the printed gazette that was often bundled with the manuscript letter or, at the very least, was assumed to have been read by the recipient. References to the printed news in the letters are often followed by phrases like "to which I can onely add" and "I shall not need to repeat it here But shall add what is not made publick." ${ }^{40}$ In April, 1678, Muddiman opens a very short newsletter with an apology: "There is But little to write to you at prsent [sic] for all the account wee have had since my last . . . is In the Newes booke." ${ }^{11}$ The writers clearly position their information as supplementary to the public news, as information meant for a more elite class of reader who can be trusted with sensitive details both with respect to the political events outlined in the papers but also with respect to the gossipy anecdotes. The supplementary nature of the manuscript letters has led J.G. Muddiman to argue that "printed news actually became subsidiary to the written news" during this period and certainly the letters themselves rhetorically worked to produce that hierarchy of news media. ${ }^{42}$

The representation of the manuscript newsletters as privileged is further evidenced in editorializing moments and political commentary in the letters, for as Sutherland reminds us with regard to printed news, "any political comment in this period was potentially dangerous." ${ }^{43}$ Even allowing for the greater privilege afforded to manuscript, the writers were still careful to distance themselves from the political sentiments alluded to in their reports. Thus a letter written to Christopher Bowman during the succession crisis relates the following after the Duke of Monmouth's disobedient return to London despite his being dismissed from court by Charles II: "Some give out that the Duke of Monmouth has been introduced by some persons of quality to his Majesty's presence, but 'tis certain his servants do not own any such thing, though they, as well as others, hope in a little time his Majesty may receive him into favour" (my italics) ${ }^{44}$ Carefully couching the support for Monmouth as something others may feel, the newsletter writer dangerously expresses that support while distancing himself from it. Another newsletter from the same period explicitly reveals this danger in its brief note to an unnamed recipient that the letter writer has been "taken notice of" by the Council. ${ }^{45}$ As Mark Knights reminds us "the government was as sensitive about the potentially seditious nature of manuscript news as it was about printed material," and yet, to get around this, the newsletter writers often used a sort of rhetorical disavowal to include the information while distancing themselves from opinions which could be considered politically sensitive. ${ }^{46}$ 
Other types of editorializing were less dangerous but just as important for shaping their audience as an elite group of readers. In a newsletter sent to Sir Leoline Jenkins when he was serving as a plenipotentiary to the congress of Nijmegen, we find a news writer's complaint about the currency of information in London: "wherever one comes one can heare no other discourse, but what concernes the present state of things, there being no man of how meane a capacity or station whatsoever but is able to make reflections and even arraigne the king's proceedings." ${ }^{77}$ The writer here is implicitly contrasting the recipient of his letter to the London public, the many individuals of "meane . . capacity or station" who are reading or in many cases having the news read to them in London's coffee houses. This is not to say that the recipients of the manuscript newsletters all belonged to the gentry class, though Jenkins himself certainly did; even with the evidence that we have, it is difficult to say who had access to these letters. While some country gentlemen did pay five pounds a year to Muddiman for his twice-weekly letters, many were sent out in exchange for news from abroad and, once sent, many were certainly circulated even further through the making of copies and oral dissemination. ${ }^{48}$ The point is that the letters themselves rhetorically construct their audience in a particular fashion, emphasizing their readers' elite access to information and setting them above the London public. This portrait of the ideal readers of these letters reinforced the recipients' desire for them and the news they contained by allowing them to feel part of an elite group of knowledgeable readers.

In reality, the manuscript newsletters being written from Whitehall were not substantively different from the printed London Gazette, and, for a brief period in the mid 1660s, were even written by the same person, Henry Muddiman. Both media contain mainly foreign news, with local items mostly restricted to appointments, election results, and official proclamations. However, there are a few important differences between the manuscript and the print, differences that can be grouped into two categories: information tracking the movements of the king and personal items about Charles's favorites. The printed papers do contain occasional items about Charles or members of the court traveling about the countryside, as well as gossipy items like the Domestick Intelligence's report of the death of Nell Gwyn's mother, who "sitting lately near the water-side, at her House by the Neat Houses near Chelsey, fell accidentally into the water and was drowned."49 However, for the most part, these notices lack the detail provided by manuscript letters, are rarely in the official newspaper (as opposed to the opposition papers), and, in the case of the gossipy items, are very few and far between.

In contrast, manuscript letters contain more frequent reports of the private lives of the aristocracy, though it must be stressed that this type of item is still infrequent in comparison to the other types of information contained in the letters. Often this type of report appears through its own negation, when the writer is at pains to "correct" gossip or "report" that is circulating around London. Thus, one of the Newdigate newsletters contains the report of a robbery of the Lord Chancellor's house and lists the items that were stolen. The writer justifies his detailing of the stolen goods by referencing "a Jolley Report about towne" which claimed that "the greate seale had Been Carried away with them." ${ }^{0}$ When the newsletter writers are merely relaying gossip, they flag it as such, distancing themselves 
from the less reliable information. Thus, the writer of a letter to Jenkins ends his report about George Villiers, Duke of Buckingham being spotted unexpectedly in France, likely on "an Expedition of amour," with the following cautionary statement: "but I tell your Ex ${ }^{1 y}$ this onely as a report, as I heare it in every bodys mouth." ${ }^{51}$ This caution against spreading unsubstantiated report while still conveying potentially important information is demonstrated most clearly in a passage about an explosion in London on June 24, 1682, included in a newsletter addressed to the Pole family; at the end of the report, the writer concludes that "this affair is lookt upon as very exstrordnary, But we shall make noo Coments theroon only giving true matter of ffact $\&$ leave it to every body to make their own Romances." ${ }^{2}$ Explicitly distancing the newsletter from the romance, the writer adeptly negotiates the need to pass the information along to his correspondents with the possibility that the "report" may lack substance.

One of the advantages of manuscript for this type of information is its implication of privacy against the publicity of print; as Love explains, even when the newsletters were copied out by a clerk, "the fiction was usually maintained that the letter was a personal communication between gentlemen. ${ }^{53}$ In their mimicking of direct, personal communication, the manuscript newsletters are affectively more akin to oral conversation than the printed newspapers that accompanied them. The inclusion of gossipy items and occasional editorializing by the writers heighten this effect, conferring upon the letters an air of the "participatory discourse" that Nicola Parsons ascribes to eighteenth-century gossip, a discourse that "creates a bond of intimacy between those who engage in its processes." 54

In a court as volatile as Charles II's, gossip provided important politically sensitive information about who was in or out of favor with the King and his leading ministers and mistresses; it was an important part of political discourse. As Weil argues, "the rises and falls of women in Charles's favor were watched closely not merely out of prurient interest but as portents of shifts in the king's policies. ${ }^{\text {"5 }}$ Information about current court favorites would be essential to a gentleman who spent a good part of the year in the country or a courtier who happened to be temporarily out of the country, like Jenkins. But in addition to this practical element, gossipy information also provided an affective link to that court, allowing the recipients of the letters to feel as if they were a part of the community surrounding the king. This affective intimacy, based in the supplementary, exclusive knowledge promised by the letters, was intensified by the final aspect of the newsletters that this article will address: their supplementarity with regard to the person of the king, created for their audiences by the attention paid to the movements of Charles and his court around the English countryside.

When one reads contemporary accounts of Charles II's movements in manuscript newsletters, the overriding impression is one of a king perpetually in motion and a country trying to keep up. ${ }^{56}$ This effect would have been reinforced for those living in the greater London area by their ability, occasionally, to see the king out and about, as evidenced by the many times Charles is mentioned in contemporary memoirs and diaries out hunting, walking in St. James's Park, taking in the horse races, watching a play in one of the public theatres, or playing tennis. ${ }^{57}$ Charles's motion is what often made him accessible to his subjects. His speed and occasional unpredictability in his travels were 
what allowed him to outstrip the layers of courtiers who surrounded him, leaving him open to informal encounters as long as one had the appearance of a gentleman. Charles's availability to the public is noted in Thomas Sprat's account of the Rye House Plot, which includes a long list of places considered by the conspirators as easy locations in which to surprise the king and his brother, including in St. James's Park, walking down to the river "for their Divertisement," in the playhouse, in Covent Garden, or while they were on the road between Windsor and Hampton Court or London and Newmarket. ${ }^{58}$

Charles's informal public visibility created the dynamic of elusiveness/availability that I argue is an important paradox alongside the other antithetical qualities that make Charles II, for Roach, the first celebrity. His motion—grounded in the strength of his physical/athletic body, celebrated in narratives like those of his escape from Worchester during the Interregnum, and reinforced by his constant travels—created a desire in his subjects to keep up with the king, whether that meant keeping up with the gossip surrounding his sexual exploits, keeping abreast of his movements around London and between London and his favorite sporting retreats, or literally keeping up with him while walking in order to bend his ear in one's own favor.

The official print newspaper The London Gazette contained reports of Charles's travels between his favorite pleasure spots; however, the printed reports are most often about past movements, indicating where the court has travelled but not generally what their future movements may be, and appear with far less frequency than those in the manuscript newsletters, which are more detailed and include both travels already accomplished and journeys planned for the future. This is demonstrated clearly by comparing the reports of the king's movements contained in both the official print paper and the newsletters written out of Whitehall during the same month.

In April, 1674, the print news includes a report that "This day His Majesty, accompanied with his Royal Highness, and attended by several of the Nobility, and other persons of quality, returned hither from Newmarket in perfect health." ${ }^{39}$ In the same month, the newsletters contain the following items "Thursday morning his Maty wth his attendance went by 5 a clock to new market severall persons of honnour being gone before. his Maty thinks to Returne abt Saterday next," "From Newmarket we heare that his Majestie arrived there on thursday about 4 of the Clock where his stay is not like to be long for theire are noe Matches yet or like to be," "on Saterday the King setts out from thence [Newmarket] \& intends to be at home by noone," "Orders are gone to ye Greene Clothe to cause all things to be prepared for ye Reception of his Maty at Windsor on ye 20th of May," "Sunday in the afternoon his Maty and his attendance went by water to Chattam ... and from therre he thinks to proceed to Harwich. ... On Tuesday Evening his Majesty and Royall Highness returned to towne from Chattam and Sherenesse." ${ }^{60}$ Far more detailed than The London Gazette reports, the newsletters paint a vivid picture of the king in motion. Moving well beyond informational purposes, these frequent reports of the king's activities imaginatively stand in as access to the king himself, building, through their repetition, a strong affinity between the recipient and the court. What differentiates this effect created during the 1670s between Charles and his subjects by the manuscript newsletters from other media relationships is Charles's own reinforcement of the persona. 
Brian Weiser has pointed out that informal vacation spots like Newmarket offered for Charles a "relaxed formality" that "allowed [him] to interact more intimately with his subjects." ${ }^{61}$ As Sir John Reresby writes in his memoirs, at Newmarket the King "lett himself down from Majesty to the very degree of a country gentleman. He mixt himselfe amongst the croud, allowed every man to speak to him that pleased, went a-hawkeing in mornings, to cock matches in afternoons (if ther were noe hors races), and to plays in the evenings." ${ }^{2}$ This link between Charles's informality, his physical pursuits, and his movements outside of London can also be seen in the Newdigate newsletters as they try to track his movements out sailing on a loosely scheduled trip down to Portsmouth and Plymouth. The letter writer reports the trip, noting that the plan is to continue on to Plymouth "if the Weather permitt." 63 The next letter notes that the Dukes of York and Monmouth have in fact arrived at Portsmouth but the king has overshot the mark and is on the far side of the Isle of Wight. From here the king goes to Portsmouth and then eventually on to Plymouth. The letter also notes that officials in Plymouth are only told of his Majesty's planned visit by an express from the Earle of Bath. ${ }^{64}$ Charles's tendency to take unplanned excursions and detours kept the country gentry and town officials on their toes but also opened up the possibility for his subjects to unexpectedly see the king, even if they were not in the center of London. This possibility was enhanced in the people's minds by the public reports that circulated further and more frequently than the king himself, deepening his subjects' sense of knowing him.

Like the gossip that draws the reader into a community of privileged insiders and the emphasis on the newsletter as supplement that implies a politically elite cognoscenti, the attention to the particulars of the king's movements creates an imagined bond between the newsletter readers and the court. The readers' knowledge of the king's location allowed them to imaginatively follow the court, vicariously becoming a part of the public activities of their monarch despite the physical distance from his actual presence. The newsletters do not merely convey the information about the king's whereabouts; through their supplementarity, they stand in for the king, providing access to the man out enjoying sailing, taking in the cock fights, or being entertained at the theatre with his current mistress.

The fact that these letters were semi-official and marked as originating from Whitehall, opens up the possibility that they were part of Charles II's larger strategy to create an image of an accessible monarch in sharp contrast to the ultimately tragic distance his late father created between himself and his people. This implication leads us back to the image with which I began: the king's immediate hand directing and creating an imagined community of privileged knowledge surrounding his throne- a community to which he actually revealed very little but that was affectively tied to the king through the rhetorical shaping enacted by the manuscript newsletters. 


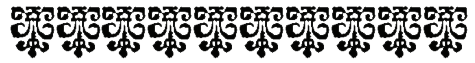

\section{Notes}

${ }^{1}$ The archival work necessary for this article was made possible by the generous support of the SSHRC Insight Development Grant Program, the University of Manitoba's University Research Grant Program and New Faculty Start-Up Funding.

29 November 1677, Newdigate Newsletters, Numbers 1 through 2100 (13 January 1673/4 through 11 June 1692), transcribed and ed. Philip Hines, Jr., Folger Shakespeare Library, electronic resource.

${ }^{3}$ In his introduction to the typescript of the Newdigate Newsletters, Philip Hines notes that letters from Muddiman, a friend of Sir Richard's, comprise a significant part of the collection. Muddimen's newsletters are identified by the "Whitehall" heading, which he had the exclusive right to use.

${ }^{4}$ Strong work has been done on what Alison Conway terms "the fear of female rule" (36) that characterized much of the Restoration literature and polemic about Charles's mistresses. See in particular Alison Conway, The Protestant Whore: Courtesan Narrative and Religious Controversy in England, 1680-1750 (Toronto: University of Toronto Press, 2010) and Rachel Weil, "The Female Politician in the Late Stuart Age," in Politics, Transgression, and Representation at the Court of Charles II, eds. Julia Marciari Alexander and Catherine MacLeod (New Haven: Yale Center for British Art, 2007), 171-91.

${ }^{5}$ Rachael Scarborough King examines the supplemental nature of the newsletters from a different angle in her analysis of letters from the 1690s in the Pole Family News Collection. These later letters combine print and manuscript news demonstrating the "co-evolution and ongoing correspondence between scribal and printed notices" (435) at the time. "The Manuscript Newsletter and the Rise of the Newspaper, 1665-1715," Huntington Library Quarterly 79, no. 3 (Autumn 2016): 411-437.

${ }^{6}$ Brian Weiser argues that Charles understood "the significance of access and capitalized upon it" (24) strategically manipulating the levels of access he allowed to his courtiers depending on the political climate. See Brian Weiser, Charles II and the Politics of Access (New York: Boydell Press, 2003). Although Charles maintained a high level of accessibility early on in his reign, he receded from that stance as politics became more factious in the late 1670s. See also Jenny Uglow, Charles II's Restoration Game (New York: Farrar, Straus and Giroux, 2009) and Mark Knights, Politics and Opinion in Crisis, 167881, Cambridge Studies in Early Modern British History, eds. John Guy and John Morrill Anthony Fletcher (New York: Cambridge University Press, 1994; 2006). 
${ }^{7}$ Jacques Derrida, Of Grammatology, trans. Gayatri Chakravorty Spivak, corrected edition (Baltimore: Johns Hopkins University Press, 1997, 1974), 144-45. Page references are to the 1997 corrected edition.

${ }^{8}$ Kevin Sharpe, “'Thy Longing Country's Darling and Desire': Aesthetics, Sex, and Politics in the England of Charles II," in Politics, Transgression, and Representation at the Court of Charles II, eds. Julia Marciari Alexander and Catherine MacLeod, Studies in British Art (New Haven: Yale Center for British Art, 2007), 1-32 and Rebranding Rule: The Restoration and Revolution Monarchy, 1660-1714 (New Haven: Yale University Press, 2013), 171-72. Roach, It (Ann Arbor: University of Michigan Press, 2007), 8.

${ }^{9}$ Lorenzo Magalotti, Lorenzo Magalotti at the Court of Charles II: His Relazione D'inghilterra of 1668 , trans. W. E. K. Middleton (Waterloo: Wilfred Laurier University Press, 1980), 28.

${ }^{10}$ William Matthews, ed., Charles II's Escape from Worcester: A Collection of Narratives Assembled by Samuel Pepys (Berkeley: University of California Press, 1966).

${ }^{11}$ Sharpe argues that Charles "was the first monarch to pursue popularity by means of an image of ordinariness," a strategy that he ascribes not merely to "personal preference and experience" but rather to Charles's "shrewd political sense." Rebranding Rule, 193. Uglow argues that Charles's frequent theater-going was part of this "strategy of openness," Restoration Game, 277.

${ }^{12}$ In his argument for Charles II as the first modern celebrity, Roach stresses the importance of the celebrity figure's embodiment of contradictory traits, "marks of strength" and "signs of vulnerability" which Roach terms "charismata" and "stigmata" respectively. It, 36 .

${ }^{13}$ Sharpe, Rebranding Rule, 93.

${ }^{14}$ Tim Harris, "There Is None That Loves Him but Drunk Whores and Whoremongers': Popular Criticisms of the Restoration Court," in Politics, Transgression, and Representation at the Court of Charles II, eds. Julia Marciari Alexander and Catherine MacLeod. Studies in British Art (New Haven: Yale Center for British Art, 2007), 43.

${ }^{15}$ Andrew Browning, ed., Memoirs of Sir John Reresby: The Complete Text and a Selection from His Letters, 2nd ed. (London: Royal Historical Society, 1991), 112-13.

${ }^{16}$ Robert Latham and William Matthews, eds., The Diary of Samuel Pepys. 11 vols. (Berkeley: University of California Press, 1970-83), 8:181. 
${ }^{17}$ Osmund Airy, ed., Burnet's History of My Own Time: Part 1: The Reign of Charles the Second, 2 vols. (Oxford: Clarendon Press, 1897), 1:166.

${ }^{18}$ Sharpe, "Aesthetics, Sex, and Politics"

${ }^{19}$ Harris, "Popular Criticisms," 43. See also Sharpe, Rebranding Rule, 214-15, where he labels Rochester's satires on the king as "to say the least, equivocal." Harold Love also touches on this in his discussion of court lampoons, arguing that while the poems written about Louise de Kéroualle depicted her sexuality as an aberrant reflection of her attempts to assert political power at court, the satires written about Nell Gwyn, "who offers the king pleasure without in any way wishing to encroach on his prerogative," celebrate her as "a champion not only of Protestantism but of orthodox intercourse." Harold Love, English Clandestine Satire: 1660-1702 (Oxford: Oxford University Press, 2004), 60.

${ }^{20}$ For more on the affective ambiguity activated by secret histories about Charles II, see Erin Keating, "In the Bedroom of the King: Affective Politics in the Restoration Secret History," Journal of Early Modern Cultural Studies 15, no. 2 (Spring 2015): 58-82.

${ }^{21}$ Latham and Matthews, ed., Diary of Samuel Pepys, 1:158, 6:170.

${ }^{22}$ Ibid, 9:19-20.

${ }^{23}$ Weil, "Female Politician,” 181.

${ }^{24}$ Joseph Roach, "Celebrity Erotics: Pepys, Performance, and Painted Ladies," in Politics, Transgression, and Representation at the Court of Charles II, eds. Julia Marciari Alexander and Catherine MacLeod. Studies in British Art (New Haven: Yale Center for British Art, 2007), 244.

${ }^{25}$ Knights argues that the loyalist side was "reluctant [...] to go into print," particularly during times of crisis, meaning that the print material about Charles II would have had a decidedly oppositional tone. This would have made the manuscript newsletters written from Whitehall the more important, as Knights writes, “Muddiman's importance in conveying loyalist sentiments to the gentry and nobility was possibly second only to that of L'Estrange." Politics and Opinion, 166, 176.

${ }^{26}$ Roach, It, 17.

${ }^{27}$ Roach, It, 175.

${ }^{28}$ Robert Adams Day, Told in Letters: Epistolary Fiction before Richardson (Ann Arbor: University of Michigan Press, 1966), 11. 
29 James Sutherland, The Restoration Newspaper and Its Development (Cambridge: Cambridge University Press, 1986), 29.

${ }^{30}$ Ibid., 30.

${ }^{31}$ Roach, “Celebrity Erotics,” 236.

32 Patricia Meyer Spacks, Gossip (Chicago and London: University of Chicago Press, 1985), 261.

33 The range of documents included under the label manuscript newsletters is extremely broad and differs between scholars. For the purposes of this article, I am focusing mainly on the newsletters that would be considered royalist, having been written from Whitehall or, in the case of the letters to Sir Leoline Jenkins, written for a court official who was shortly thereafter appointed one of the Secretaries of State.

${ }^{34}$ David Randall, "Epistolary Rhetoric, the Newspaper, and the Public Sphere," Past and Present, no. 198 (Feb. 2008): 3-32, 23.

35 Qrd. in Andrew Mousley, "Self, State, and Seventeenth-Century News," The Seventeenth Century 6, no. 2 (Fall 1991): 149-68, 158; Sutherland, Restoration Newspaper, 102.

${ }^{36}$ Heiko Droste, "Degrees of Publicity. Handwritten Newspapers in the Seventeenth and Eighteenth Centuries," LIR.Journal, no. 1 (2011): 68-83, 70. Harold Love, Scribal Publication in Seventeenth-Century England (Oxford: Clarendon, 1993).

${ }^{37}$ King, "The Manuscript Newsletter," 412, 414.

${ }^{38} \mathrm{~A}$ lot of research is being done in Europe on the continuing importance of manuscript newsletters for circulating politically sensitive information well into the twentieth century. A workshop on the subject featured multiple presentations on nineteenth- and twentiethcentury manuscript newsletters in the United States (Mark Alan Mattes, Mary Isbell), in the labor movements of Finland (Risto Turunen) and Norway (Christian Berrenberg), and in Calvinist communities in Transylvania (Emese Ilyefalvi); this work has unfortunately not appeared in any English publications as of the publication of this article. "Handwritten Newspapers as an Alternative Medium During the Early Modern and Modern Times", workshop, Uppsala University, Sweden, September 17-18, 2015.

${ }^{39}$ Love, Scribal Publication, 73-79.

${ }^{40}$ Newdigate Newsletters, 2 June 1676, 7 July 1676. 
${ }^{41}$ Newdigate Newsletters, 4 April 1678.

${ }^{42}$ J. G. Muddiman, The King's Journalist: 1659-1689, Studies in the Reign of Charles II (New York: Augustus M. Kelley Publishers, 1923. 1971), 166.

${ }^{43}$ Sutherland, Restoration Newspaper, 4.

${ }^{44}$ Newsletter to Christopher Bowman, Newcastle-on-Tyne, 11 December 1679, Calendar of State Papers, Domestic series, of the reign of Charles II, 1679-1680, ed. F.H. Blackburne Daniell vol. 21 (London: His Majesty's Stationary Office, 1915), State Papers Online.

${ }^{45}$ Newsletter, 18 December 1679, State Papers Online.

${ }^{46}$ Knights, Politics and Opinion, 176.

${ }^{47}$ Newsletter to Sir Leoline Jenkins, 17 May 1678, Newsletters to Sir Leoline Jenkins, HM 30314-30315, The Huntington Library.

${ }^{48}$ Peter Fraser gives us some sense of the dissemination of the manuscript newsletters written out of the Secretary of State's office in a chart detailing Joseph Williamson's domestic correspondents from 1667-69. Though certainly this is only a small fraction of the readers who may have eventually gained access to the newsletters through user copies and oral dissemination. See Peter Fraser, The Intelligence of the Secretaries of State and Their Monopoly of Licensed News: 1660-1688 (Cambridge: Cambridge University Press, 1956), 30. I am grateful for the report from Zsuzsa Barbarics-Hermanik, who has encountered English manuscript newsletters from the late seventeenth-century in her research in the Turkish archives, demonstrating the geographical reach of these newsletters.

49 Domestick Intelligence, or, News both from the City and Country, 5 August 1679, Newberry Library. Appearing in Benjamin Harris's opposition paper, the implication available to Harris's readers would have been that Gwyn's mother was drunk when she drowned.

${ }^{50} 10$ February 1676, Newdigate Newsletters.

5123 August 1678, HM 30314-30315.

${ }^{52}$ Newsletter, 24 June 1682, Pole Family News Collection, MS.1951.021, William Andrews Clark Memorial Library.

${ }^{53}$ Love, Scribal Publication, 11. 
${ }^{54}$ Nicola Parsons, Reading Gossip in Early Eighteenth-Century England (New York: Palgrave Macmillan, 2009), 34.

55 Weil, “Female Politician,” 182.

56 For a succinct summary of Charles II's travels during his reign, see Sharpe, Rebranding Rule, 192.

${ }^{57}$ Instances of Charles's athleticism are evident throughout the diaries and memoirs mentioned in this article. For a summary of Charles's physical pastimes, see Ronald Hutton, Charles the Second: King of England, Scotland, and Ireland (Oxford: Clarendon Press, 1989), 443.

58 Thomas Sprat, A True Account and Declaration of the Horrid Conspiracy against the Late King, His Present Majesty, and the Government: As It Was Order'd to Be Published by His Late Majesty (London: Thomas Newcomb, 1685), 50-51.

59 The London Gazette, 9 April - 13 April 1674, Folger Shakespeare Library.

${ }^{60}$ 2, 7, 9, 23, 28 April 1674, Newdigate Newsletters.

${ }^{61}$ Weiser, Politics of Access, 36.

${ }^{62}$ Browning, ed., Memoirs, 259.

6326 June 1675, Newdigate Newsletters.

${ }^{64} 1$ July 1675, Newdigate Newsletters.

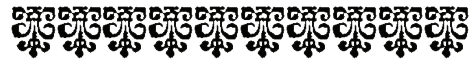

\section{Works Cited}

Airy, Osmund, ed. Burnet's History of My Own Time: Part 1: The Reign of Charles the Second. 2 vols. Oxford: Clarendon Press, 1897.

Barbarics-Hermanik, Zsuzsa. "Handwritten Newsletters as a Means of Transcultural Communication in the Ottoman Empire and beyond." Presentation at the workshop, "Handwritten Newspapers as an Alternative Medium During the Early Modern and Modern Times”, Uppsala University, Sweden, September 17-18, 2015. 
Brémond, Sébastien. Hattige: Or the Amours of the King of Tamaran. Amsterdam: Simon the African [R. Bentley], 1680.

Browning, Andrew, ed. Memoirs of Sir John Reresby: The Complete Text and a Selection from His Letters. 2nd ed. London: Royal Historical Society, 1991.

Calendar of State Papers, Domestic series, of the reign of Charles II, 1679-1680, ed. F.H. Blackburne Daniell vol. 21 (London: His Majesty's Stationary Office, 1915), State Papers Online.

Conway, Alison. The Protestant Whore: Courtesan Narrative and Religious Controversy in England, 1680-1750. Toronto: University of Toronto Press, 2010.

Day, Robert Adams. Told in Letters: Epistolary Fiction before Richardson. Ann Arbor: University of Michigan Press, 1966.

Derrida, Jacques. Of Grammatology. Translated by Gayatri Chakravorty Spivak. Corrected Edition ed. Baltimore: Johns Hopkins University Press, 1997. 1974.

Domestick Intelligence, or, News both from the City and Country (Benjamin Harris), 5 August 1679, Newberry Library.

Droste, Heiko. "Degrees of Publicity. Handwritten Newspapers in the Seventeenth and Eighteenth Centuries." LIR.Journal, no. 1 (2011): 68-83.

Fraser, Peter. The Intelligence of the Secretaries of State and Their Monopoly of Licensed News: 1660-1688. Cambridge: Cambridge University Press, 1956.

Harris, Tim. “'There Is None That Loves Him but Drunk Whores and Whoremongers': Popular Criticisms of the Restoration Court." In Politics, Transgression, and Representation at the Court of Charles II, edited by Julia Marciari Alexander and Catherine MacLeod. Studies in British Art, 35-58. New Haven: Yale Center for British Art, 2007.

Hutton, Ronald. Charles the Second: King of England, Scotland, and Ireland. Oxford: Clarendon Press, 1989.

Keating, Erin. "In the Bedroom of the King: Affective Politics in the Restoration Secret History." Journal of Early Modern Cultural Studies 15, no. 2 (Spring 2015): 58-82.

King, Rachael Scarborough. "The Manuscript Newsletter and the Rise of the Newspaper, 1665-1715.” Huntington Library Quarterly 79, no. 3 (Autumn 2016): 411-437. 
Knights, Mark. Politics and Opinion in Crisis, 1678-81. Cambridge Studies in Early Modern British History. Edited by John Guy and John Morrill Anthony Fletcher New York: Cambridge University Press, 1994. 2006.

Latham, Robert, and William Matthews, eds. The Diary of Samuel Pepys. 11 vols. Berkeley: University of California Press, 1970-83.

The London Gazette, 9 April - 13 April 1674, Folger Shakespeare Library.

Love, Harold. English Clandestine Satire: 1660-1702. Oxford: Oxford University Press, 2004.

---. Scribal Publication in Seventeenth-Century England. Oxford: Clarendon, 1993.

Magalotti, Lorenzo. Lorenzo Magalotti at the Court of Charles II: His Relazione D'inghilterra of 1668. Translated by W. E. K. Middleton. Waterloo: Wilfred Laurier University Press, 1980.

Matthews, William, ed. Charles Ii's Escape from Worcester: A Collection of Narratives Assembled by Samuel Pepys. Berkeley: University of California Press, 1966.

Mousley, Andrew. "Self, State, and Seventeenth-Century News." The Seventeenth Century 6, no. 2 (Fall 1991): 149-68.

Muddiman, J. G. The King's Journalist: 1659-1689. Studies in the Reign of Charles II. New York: Augustus M. Kelley Publishers, 1923. 1971.

Newdigate Newsletters. Numbers 1 through 2100 (13 January 1673/4 through 11 June 1692), transcribed and edited by Philip Hines, Jr., Folger Shakespeare Library, electronic resource.

Newsletters to Sir Leoline Jenkins, HM 30314-30315, The Huntington Library.

Parsons, Nicola. Reading Gossip in Early Eighteenth-Century England. New York: Palgrave Macmillan, 2009.

Pole Family News Collection, MS.1951.021, William Andrews Clark Memorial Library.

Randall, David. "Epistolary Rhetoric, the Newspaper, and the Public Sphere." Past and Present, no. 198 (Feb. 2008): 3-32.

Roach, Joseph. It. Ann Arbor: U of Michigan P, 2007. 
---. "Celebrity Erotics: Pepys, Performance, and Painted Ladies." In Politics, Transgression, and Representation at the Court of Charles II, edited by Julia Marciari Alexander and Catherine MacLeod. Studies in British Art, 233-50. New Haven: Yale Center for British Art, 2007.

Sharpe, Kevin. Rebranding Rule: The Restoration and Revolution Monarchy, 1660-1714. New Haven: Yale University Press, 2013.

---. "Thy Longing Country's Darling and Desire': Aesthetics, Sex, and Politics in the England of Charles II." In Politics, Transgression, and Representation at the Court of Charles II, edited by Julia Marciari Alexander and Catherine MacLeod. Studies in British Art, 1-32. New Haven: Yale Center for British Art, 2007.

Uglow, Jenny. Charles II’s Restoration Game. New York: Farrar, Straus and Giroux, 2009.

Spacks, Patricia Meyer. Gossip. Chicago and London: University of Chicago Press, 1985.

Sprat, Thomas. A True Account and Declaration of the Horrid Conspiracy against the Late King, His Present Majesty, and the Government: As It Was Order'd to Be Published by His Late Majesty. London: Thomas Newcomb, 1685.

Sutherland, James. The Restoration Newspaper and Its Development. Cambridge: Cambridge University Press, 1986.

Weil, Rachel. "The Female Politician in the Late Stuart Age." In Politics, Transgression, and Representation at the Court of Charles II, edited by Julia Marciari Alexander and Catherine MacLeod, 171-91. New Haven: Yale Center for British Art, 2007.

Weiser, Brian. Charles II and the Politics of Access. New York: Boydell Press, 2003. 